ŁUKASZ TANAŚ 『 https://orcid.org/0000-0001-8038-8225

Wydział Psychologii, SWPS Uniwersytet Humanistycznospołeczny, Warszawa Faculty of Psychology, SWPS University, Warsaw e-mail: 1tanas@swps.edu.pl

OLGA STĘPIEŃ

Wydział Psychologii, SWPS Uniwersytet Humanistycznospołeczny, Warszawa Faculty of Psychology, SWPS University, Warsaw e-mail: ostepien@st.swps.edu.pl

\title{
Styl więzi, empatia i kody moralne jako predyktory postaw względem zachowań seksualnych okresu dzieciństwa
}

\author{
Attachment Style, Empathy and Moral Foundations \\ as Predictors of Attitudes Towards Sexual Behavior during Childhood
}

\begin{abstract}
The study explores the structure of adult $\left(\mathrm{N}=170, \mathrm{M}_{\mathrm{age}}=30\right)$ beliefs regarding the sexuality of preschool children (Ratkowska-Pasikowska, Pasikowski, 2013). Furthermore it evaluates the probable predictors of these beliefs: avoidance and anxiety dimensions of attachment, moral foundations and the levels of cognitive and affective empathy. Results show a two-factor differentiation of beliefs regarding children's sexuality. Adults make a distinction between intrusive behaviors, related to verbal aggression or potential violation of other people's intimacy, and behaviors combining sexuality with curiosity and role-playing. The former category is generally less accepted than the latter. At the same time, higher level of cognitive empathy and a lower level of endorsement in the sphere of purity/sanctity as a foundation of moral evaluation, is a general predictor of higher acceptance of sexual behaviors in both categories. Higher level of attachment anxiety predicts a higher acceptance of intrusive sexual behaviors, and a higher level of attachment avoidance predicts a lower acceptance of such behaviors. These results are discussed within the context of their importance for the future studies on childhood sexuality with parents as the potential informants on behavior of their children.
\end{abstract}

Keywords: sexuality; attachment style; empathy; moral foundations

Słowa kluczowe: seksualność; styl więzi; empatia; kody moralne

\section{WPROWADZENIE}

Wiedza dotycząca zachowań seksualnych dzieci i młodzieży nie ma solidnych podstaw empirycznych. Dopiero ostatnia edycja kanonicznego podręcznika psychologii rozwoju wydaw- nictwa Wiley (Lamb, Lerner, 2015) zawiera osobny rozdział poświęcony temu zagadnieniu. Ponadto zdecydowana większość istniejących danych odnosi się konkretnie do ofiar nadużyć seksualnych, a niezwykle rzadko bada się powszechne, typowe aspekty seksualności dzieci, 
które mogą mieścić się w normie rozwojowej (de Graaf, Rademakers, 2011). Jeśli dodamy do tego fakt, że większość badań empirycznych w psychologii prowadzona jest zaledwie w kilku krajach (Henrich, Heine, Norenzayan, 2010), okaże się, że rzetelna wiedza o typowych zachowaniach seksualnych dzieci i młodzieży, ulokowana w polskim kontekście kulturowym, jest znikoma.

Taki stan rzeczy warto zmienić, gdyż komunikacja dotycząca seksualności stanowi istotny element funkcjonowania rodziny. Jak pokazali Hanneke de Graaf i współpracownicy (de Graaf, Vanwesenbeeck, Woertman, Meeus, 2011), wysoki poziom postrzeganego wsparcia rodziców przewiduje późniejsze rozpoczęcie aktywności seksualnej dzieci, wyższy poziom dbałości o zdrowie podczas aktywności seksualnej, bardziej pozytywne postawy względem zachowań seksualnych i wyższy poziom asertywności w kontaktach seksualnych. Jednocześnie zmiana tego stanu rzeczy nie jest łatwa. Badania Luci O’Sullivan i współpracowników (O'Sullivan, Meyer-Bahlburg, Watkins, 2001) sugerują, że seksualność to obszar o wysokim potencjale konfliktu. Podczas komunikacji między rodzicami i nastolatkami często dochodzi do negatywnej percepcji intencji rodziców podejmujących próby rozmowy na ten temat. Problem ten nie występuje jedynie w rozmowach między rodzicami i dziećmi. Komunikacja między osobami dorosłymi będącymi w związkach dotycząca konfliktów w obszarze seksualności również jest postrzegana jako bardziej zagrażająca niż komunikacja dotycząca innych obszarów potencjalnie konfliktowych. Badania Uzmy Rehman i współpracowników (Rehman, Lizdek, Fallis, Sutherland, Goodnight, 2017) pokazują, że już antycypacja rozmowy na tematy seksualne powoduje wysoki poziom lęku u osób dorosłych. Ujawnianie własnych preferencji seksualnych, choć poprawia poziom satysfakcji w związku, jest dla partnerów trudne. W badaniu, w którym uczestniczyły osoby w związkach długoterminowych, wykazano, że w trakcie $\sim 15$ lat związku partnerzy podzielili się z sobą wzajemnie zaledwie połową swoich pragnień w obszarze seksualności i ujawnili zaledwie 30\% rzeczy, których nie lubią (MacNeil, Byers, 2009).
Sprawność komunikacyjna osób dorosłych w zakresie ogólnej seksualności ma istotne znaczenie, gdyż większość danych empirycznych dotyczących seksualności dzieci i młodzieży pochodzi ze sprawozdań rodziców, czyli selektywnych obserwacji zachowań własnych dzieci, ewentualnie $\mathrm{z}$ retrospekcji osób dorosłych na temat ich własnych przeżyć z dzieciństwa (de Graaf, Rademakers, 2011). Dane te są zatem filtrowane przez opinie osób dorosłych, a jednocześnie wiemy, że tematyka ta jest silnie zabarwiona afektywnie. Zgodnie ze znaczącą częścią potocznych przekonań, istnienie takiego zjawiska jak seksualność dziecięca jest negowane albo traktowane całościowo jako objaw patologii (Beisert, 2006; Dąbkowski, Dąbkowska, 2014). W takiej sytuacji kluczowe wydaje się zrozumienie struktury potocznych poglądów osób dorosłych względem seksualności dzieci i młodzieży, a także poznanie predyktorów różnic indywidualnych w zakresie tych poglądów.

\section{STRUKTURA POGLĄDÓW DOTYCZĄCYCH ZACHOWAŃ SEKSUALNYCH OKRESU DZIECIŃSTWA}

Trudnym i złożonym aspektem przekonań dotyczących seksualności jest rozróżnianie pomiędzy obszarem szeroko rozumianego zdrowia i patologii. W przypadku seksualności okresu dzieciństwa Maria Beisert (2006) wymienia kilka możliwych sposobów dokonania takiego rozróżnienia.

Pierwsze podejście traktuje wszelkie formy ekspresji zachowań seksualnych w okresie dzieciństwa jako objaw patologii. Jak zauważa M. Beisert (2006), u podłoża takiej perspektywy leży wątpliwe założenie, że zachowania seksualne są wrodzone i nie wymagają uczenia się w toku rozwoju.

Drugie podejście uznaje pewne formy zachowań seksualnych w okresie dzieciństwa za objaw patologii, ale inne formy za akceptowane, a rozróżnienie pomiędzy tymi dwoma kategoriami dotyczy percepcji różnic motywacyjnych. Z akceptacją mogą spotkać się te formy aktywności, którym można przypisać motyw poznawczy, ale już niekoniecznie hedoniczny i związany z agre- 
sją. Masturbacja podejmowana regularnie może być widziana jako motywowana hedonistycznie, ale pojedyncze przypadki takich zachowań mogą być postrzegane jako motywowane ciekawością. Innym wariantem takiego podejścia jest próba rozróżnienia zachowań autonomicznie podejmowanych przez dzieci od takich, które świadczyć mogą o nadużyciach ze strony dorosłych.

Wreszcie możliwe jest trzecie podejście, faworyzowane przez specjalistów, które jednak zapewne będzie rzadkie w poglądach potocznych, ponieważ wymaga znacznej wiedzy nie tylko z zakresu seksuologii, ale też z zakresu psychologii rozwoju człowieka. W tym podejściu za zachowania problematyczne uznaje się takie, które wyraźnie hamują rozwój innych zachowań typowych dla danego okresu, które uprawdopodabniają nadużycia seksualne poprzez obecność osób o wyraźnie zróżnicowanym wieku, które zdają się być wykonywane instrumentalnie w celu uzyskania innych dóbr lub które zdają się świadczyć o wystąpieniu uzależnienia behawioralnego i wykonywane są kompulsywnie, ze szkodą dla zdrowia (Beisert, 2006). Jest to zatem podejście, które opiera się na zindywidualizowanej ocenie danego przypadku w określonym kontekście rozwoju.

Podsumowując, przekonania dotyczące rozgraniczania zdrowia i patologii w rozwoju seksualnym dzieci mogą przyjąć przynajmniej trzy formy. Gdy postawimy pytanie o to, które $\mathrm{z}$ tych podejść jest najbardziej typowe dla potocznych poglądów rodziców, wydaje się, że przyjdzie nam rozstrzygać między podejściem pierwszym i drugim. Być może rodzice dzielą się przede wszystkim na osoby akceptujące seksualność dziecięcą i takie, które widzą w tym objaw patologii, alternatywnie - rodzice wykazują bardziej zróżnicowane poglądy i akceptują pewne kategorie dziecięcych zachowań seksualnych, lecz nie akceptują innych.

\section{DOTYCHCZASOWE BADANIA NAD PRZEKONANIAMI DOTYCZĄCYMI DZIECIĘCEJ SEKSUALNOŚCI}

Pasikowski i Ratkowska-Pasikowska (2013) stworzyli kwestionariusz dziecięcych zacho- wań seksualnych, a następnie dokonali analizy struktury tego narzędzia. Katalog zachowań seksualnych powstał na podstawie literatury przedmiotu. Choć autorzy zaznaczają, że jest to jednocześnie zestaw zachowań „,prawidłowych, w granicach normy rozwojowej" (s. 78), wydaje się, że należy do tego stwierdzenia podejść z ostrożnością. Jak wspomniano, obecny stan systematycznej wiedzy w tym obszarze jest bardzo skromny i umożliwia raczej stworzenie pewnej listy zachowań, na której znajdą się czynności, jakie zostały zaobserwowane u niektórych dzieci w określonym wieku i w danym kontekście nie zdawały się być przykładem patologii.

Kluczowe jest jednak, że autorzy sugerują, iż przeprowadzona analiza czynnikowa wskazuje na jednorodność struktury poglądów osób dorosłych na temat zachowań seksualnych dzieci. Oznaczałoby to, że ludzie dzielą się po prostu na tych, którzy wykazują większą i mniejszą akceptację tej tematyki. Można mieć jednak pewne wątpliwości odnośnie do takiej konkluzji. Autorzy podają, że ładunki czynnikowe poszczególnych pozycji analizowanego kwestionariusza miały wartości w przedziale .35-.77, a główny czynnik wyjaśniał $42 \%$ wariancji wyników. Takie wartości sugerują, że uzasadnione jest przeprowadzenie analizy czynnikowej, jednakże wyciąganie wniosków, że mamy do czynienia $\mathrm{z}$ akurat jednym czynnikiem, byłoby przedwczesne. Wydaje się raczej, że konieczne są dalsze prace nad narzędziem, gdyż minimalna wartość ładunku $=.35$ oznacza, że procent wariancji wyjaśnionej przez zmienną latentną $\mathrm{w}$ odniesieniu do tej pozycji testowej wynosi zaledwie $12 \%$. Za kryterium dobrze zdefiniowanej struktury uznaje się zazwyczaj średnie ładunki zbliżone do .7, czyli w ok. 50\% nasycone czynnikiem wspólnym (Hair, Black, Babin, Anderson, 2013). Posiadane dane nie wydają się zatem konkluzywne względem ustalenia jednorodnej struktury pozycji kwestionariusza i potrzebne są dalsze badania. Jednym z dwóch głównych celów obecnego badania jest ponowna analiza struktury narzędzia przeprowadzona na nowej próbie badanych. 
OD CZEGO MOGA ZALEŻEĆ RÓŻNICE INDYWIDUALNE W ZAKRESIE POGLĄDÓW DOTYCZĄCYCH SEKSUALNOŚCI DZIECI?

Drugim celem badania jest ustalenie, $\mathrm{z}$ czego mogą wynikać różnice dotyczące poglądów odnośnie do seksualności okresu dzieciństwa. $Z$ jednej strony jest to obszar związany z ogólną opieką i rodzicielstwem, z drugiej strony dotyczy seksualności, czyli kwestii powiązanej $\mathrm{z}$ ocenami moralnymi oraz silnie afektywnej, gdzie umiejętność rozumienia stanów umysłowych innych osób może być utrudniona przez obecność własnych skojarzeń afektywnych $\mathrm{z}$ daną sytuacją. Biorąc pod uwagę te aspekty zjawiska, w obecnym badaniu zdecydowano się na analizę trzech konstruktów: różnic indywidualnych w zakresie mechanizmów więzi, różnic w zakresie determinantów decyzji moralnych oraz efektywności procesów empatii.

Mechanizmy więzi, decyzji moralnych, empatii i opieki nad dziećmi mogą wydawać się odległe, ale przyjęcie perspektywy ewolucyjnej pozwala znaleźć w tych zjawiskach wspólny mianownik (Churchland, 2013; Hrdy, 2011). Podstawowym elementem łączącym te zjawiska jest motywacja troski o organizm inny niż własny. Dobrostan innego organizmu staje się na tyle istotny, iż pojawia się wewnętrzna motywacja wydatkowania energii na rzecz jego opieki, przewidywania jego zachowania i ochrony przed zagrożeniami. Przykładowo, u ssaków reakcja na zagrożenie względem potomstwa przypomina reakcję na ból własny, a reakcja separacji dziecka od opiekuna w mechanizmie więzi zbliżona jest do reakcji na inne zagrożenia fizycznego uszkodzenia tkanek (Churchland, 2013). U ssaków społecznych mechanizmy bezpośredniej opieki nad potomstwem, mogą odgrywać również rolę w poczuciu troski względem szerszego grona członków grupy własnej, co określamy jako afektywne mechanizmy leżące u podłoża emocji moralnych (Churchland, 2013). Empatia widziana $\mathrm{z}$ tej perspektywy jest kluczowym elementem socjalizacji, który umożliwia efektywne sprawowanie takiej opieki, zarówno umożliwiając trafne oce- ny i przewidywania dotyczące intencji innych osobników, uwzględniając możliwą odmienność ich stanów umysłowych od własnych (empatia poznawcza), jak i generując stany motywacyjne wynikające ze współodczuwania emocji wraz z innymi (empatia afektywna) (de Waal, 2008; Decety, Cowell, 2014; Decety, Svetlova, 2012).

\section{STYL WIEZZI}

Jak już wspomniano, sprawność komunikacyjna osób dorosłych w zakresie seksualności jest równie istotna, co trudna do osiągnięcia. Naturalnym kontekstem,w którym odbywa się praktyka tego rodzaju dialogu, jest rozmowa między dorosłymi partnerami będącymi w relacji seksualnej. Jakość kompetencji komunikacyjnej nabytej w tym kontekście może później przekładać się na inne rodzaje dialogu dotyczącego seksualności, w tym dialog w kontekście wychowania. Badania wskazują na powszechność oczekiwań, iż rozmowa między partnerami na tematy seksualne może wiązać się z wywołaniem emocji gniewu, wstydu lub odrzuceniem ze strony partnera, poprzez ujawnienie niezgodności, które będą trudne do akceptacji (Rehman i in., 2017). Dla wielu osób jest to również obszar, w którym brakuje gotowych skryptów dialogowych, w wyniku czego rozmowa nie jest płynna i nierzadko zawęża się do monologu (Baxter, Akkoor, 2011).

Jennifer Theiss i Roi Estlein (2014) pokazali, że szczególne trudności w zakresie komunikacji na tematy związane z seksualnością występują wtedy, gdy jednostka odczuwa wysoki poziom lęku w odniesieniu do więzi z partnerem, lub wtedy, gdy obawia się interferencji między własnymi planami i planami partnera. Ujmując te zależności w terminach wymiarów więzi, można powiedzieć, że występuje związek między wymiarem lęku oraz unikania a poczuciem zagrożenia związanego z komunikacją dotyczącą seksualności. W przypadku pozabezpiecznego stylu więzi występuje również tendencja do silniejszego odczuwania wstydu, co oznacza między innymi zatroskanie opiniami innych, poczucie, że w oczach innych nie spełnia się założonych standardów, oraz nie- 
chęć do ujawniania intymnych przekonań (Passanisi, Gervasi, Madonia, Guzzo, Greco, 2015). Większa łatwość ujawniania własnych intymnych poglądów oraz uzyskiwania analogicznych informacji od partnera jest $\mathrm{z}$ kolei mediatorem relacji między bezpiecznym wymiarem więzi a wyższym poziomem satysfakcji ze związku (Goldsmith, Dunkley, Dang, Gorzalka, 2016; Keelan, Dion, Dion, 1998).

Podsumowując, dane empiryczne wskazują na to, że konsekwencją bezpiecznego wymiaru więzi jest łatwość prowadzenia intymnej komunikacji, w tym dotyczącej relacji seksualnych. Dane te pochodzą głównie z obserwacji dialogu osób dorosłych będących w związkach erotycznych, ale obserwowane zależności przekładają się również na jakość dialogu dotyczącego tematu seksualności, który odbywa się w kontekście wychowawczym między rodzicami i nastolatkami. Wydaje się, że można się spodziewać, iż zjawisko to wystąpi również w odniesieniu do postaw względem seksualności okresu dzieciństwa. Tym bardziej że osoby charakteryzujące się bezpiecznym stylem więzi, mające bardziej rozbudowane skrypty komunikacyjne i poznawcze dotyczące obszaru seksualności, mogą również w większym stopniu być skłonne do dialogu na temat konkretnych przypadków seksualności okresu dzieciństwa. Powinno się to przejawiać relatywnie większą ,akceptacją” tego typu zachowań, gdyż dialog zakłada dopuszczenie indywidualnej oceny zachowania w określonym kontekście i np. uzgodnienie tego, jak dane zachowanie jest oceniane przez rodziców na danym etapie rozwoju dziecka.

\section{EMPATIA}

Wyniki badań wskazują, że rozmowa na tematy seksualne jest postrzegana jako potencjalnie zagrażająca. U. Rehman i współpracownicy (2017) pokazali, że w trakcie samej rozmowy konfliktowej na tematy związane z seksualnością uczestnicy starają się swoim zachowaniem minimalizować zagrożenia interpersonalne, w szczególności starają się wykazać większą synchronicznością w zakresie ciepła interperso- nalnego niż w przypadku rozmowy konfliktowej na inne tematy. Oznacza to, że próbują reagować empatycznie na oczekiwanie uśmiechu czy potwierdzenia ze strony partnera, generalnie są bardziej ostrożni w dyskusji, unikają wykazywania dominacji. Jednocześnie występują różnice indywidualne $\mathrm{w}$ zakresie sprawności tej kompetencji. Osoby charakteryzujące się wyższym poziomem empatii poznawczej potrafią dopasować styl komunikacji do partnera, np. do jej/jego stylu więzi, stanowiąc w ten sposób bufor zabezpieczający przed nadmierną reakcją stresową (Simpson, Overall, 2014).

Badania sugerują również konieczność rozróżnienia dwóch komponentów empatii. Po pierwsze, empatia wymaga systemu umożliwiającego stworzenie poznawczej reprezentacji stanów afektywnych innych osób. Rozpoznanie afektu innej osoby może się odbyć poprzez klasyfikację odebranych sygnałów afektywnych (np. ekspresje mimiczne, ton głosu), wnioskowanie na podstawie sytuacji, w której dana osoba się znajduje, czy też wnioskowanie na bazie jej przekonań lub pragnień w systemie tzw. teorii umysłu (Bird, Viding, 2014). Po drugie, abyśmy mogli mówić o empatii, musi dojść do sytuacji, w której rozpoznanie afektu innej osoby ma wpływ na stan emocjonalny osoby dokonującej tego rozpoznania (Bird, Viding, 2014). Występują znaczące różnice indywidualne w zakresie obu tych komponentów empatii. Ludzie różnią się zdolnością czy też gotowością do tworzenia poznawczych reprezentacji stanów afektywnych innych osób, co bywa określane jako empatia poznawcza. Występują również różnice indywidualne w zakresie intensywności reakcji afektywnej na owe reprezentacje, co bywa określane jako empatia afektywna (Jolliffe, Farrington, 2006).

Różnice w zakresie empatii poznawczej mogą być istotnym czynnikiem determinującym postawy względem seksualności dzieci i młodzieży. W szczególności można się spodziewać, że osoby posiadające bardziej rozbudowane reprezentacje stanów umysłowych innych osób będą potrafiły rozróżnić motywy leżące u podstaw różnych zachowań seksualnych, a przede wszystkim korygować własną perspektywę osoby dorosłej, dla której zachowania te wiążą 
się często z pożądaniem. Dodatkowo empatia poznawcza, w szczególności umiejętność odróżniania perspektywy własnej i cudzej, pozwala reagować troską, a nie osobistym dystresem, na postrzeganą krzywdę drugiej osoby (Lamm, Batson, Decety, 2007). Można przypuszczać, że w podobny sposób osoby o wyższej empatii poznawczej będą potrafiły zareagować troską na sytuacje potencjalnie budzące zażenowanie lub wstyd. Umiejętność odróżniania perspektywy własnej i cudzej wydaje się szczególnie ważna w przypadku sytuacji silnie afektywnych, gdzie własne reakcje afektywne mogą utrudniać postrzeganie stanów umysłowych innej osoby, która znajduje się w innym stanie afektywnym lub w inny sposób rozumie daną sytuację (Decety, Svetlova, 2012; Lamm, Bukowski, Silani, 2016). Jest to szczególnie istotne w przypadku reakcji afektywnych względem dzieci lub innych osób, z którymi jesteśmy w bliskich relacjach, w których zakres reprezentacji ,ja” vs. „inny” w dużym stopniu się pokrywa (Cheng, Chen, Lin, Chou, Decety, 2010).

\section{KODY MORALNE}

Jednym $\mathrm{z}$ istotnych zagadnień $\mathrm{w}$ psychologii moralności jest to, czy oceny moralne opierają się głównie na percepcji krzywdy lub niesprawiedliwości, czy też dotyczą znacznie szerszego zakresu zjawisk (Haidt, 2007). W odniesieniu do obszaru seksualności ma to szczególne znaczenie, gdyż albo jest tak, że do moralizacji seksualności dochodzi tylko wtedy, gdy można w danym zjawisku dostrzec krzywdę lub niesprawiedliwość, albo również z innych powodów, np. w wyniku niezgodności danego zachowania z kulturową normą ,czystości behawioralnej”. Z kolei to, czy dane zachowanie jest moralizowane, czyli czy podlega normom konwencjonalnym, czy moralnym, ma niebagatelne znaczenie. Już trzyletnie dzieci oceniają, że z praktyk konwencjonalnych, ale już nie z moralnych, można własnowolnie zrezygnować (Josephs, Rakoczy, 2016), a przekroczenie norm moralnych oceniane jest jako bardziej poważne i mniej zależne od kontekstu, np. opinii autorytetów, a jednocześnie zawiera silny kompo- nent afektywny (Nichols, 2002). Z innych badań wiemy z kolei, jak stabilne i niepodatne na zmiany są postawy, które mają źródła afektywne (Edwards, 1990).

W wielu kulturach występują asocjacje między czystością „,iała” i czystością moralną (West, Zhong, 2015; Zhong, Liljenquist, 2006). Nie oznacza to, że każdy rodzaj transgresji moralnej przekłada się konkretnie na potrzebę uzyskania czystości fizycznej (Earp, Everett, Madva, Hamlin, 2014), ale transgresje wywołują poczucie winy i chęć symbolicznego „oczyszczenia” w postaci re-afirmacji określonych wartości, redukcji rozbieżności między obrazem siebie a moralnym punktem odniesienia (West, Zhong, 2015). Zakres sytuacji, które wyzwalają poczucie „nieczystości”, jest specyficzny kulturowo, ale można odnaleźć pewne prawidłowości. Poczucie „nieczystości” może być wywołane przez sytuacje, w których ktoś czuł się nieautentycznie, czyli wyrażał postawy czy opinie niezgodne z własnymi głębokimi przekonaniami (Gino, Kouchaki, Galinsky, 2015), ale większość norm „czystości” odnosi się do kwestii cielesnych. Pascale Sophie Russell i Roger Giner-Sorolla (2013) dowodzą, że niesmak spowodowany transgresjami „cielesnymi”, z obszaru seksualności, jest szczególnie mało podatny na procesy poznawczej reinterpretacji. Jednocześnie potępienie moralne wynikające z odczucia wstrętu wydaje się nie wymagać konieczności generowania poznawczych uzasadnień. W przeciwieństwie np. do odczucia moralnego gniewu, gdzie konieczne zdaje się wykazanie związków przyczynowo-skutkowych, które pozwalają pociągnąć do odpowiedzialności kogoś, kto wyrządził drugiemu krzywdę, przy odczuciu moralnego wstrętu ludzie nie czują konieczności poznawczego uzasadniania tej reakcji. Do zbliżonych konkluzji prowadzą badania nad tzw. asymetrią dopuszczalności fikcji (Sabo, Giner-Sorolla, 2017). Badacze pokazali, że ludzie są raczej skłonni akceptować akty wyrządzania krzywdy wtedy, gdy otrzymują informację, że jest to czyn ,fikcyjny”. Nie traktują zatem fikcyjnych „krzywd” jako transgresji moralnych, natomiast podobna reinterpretacja poznawcza nie odnosi się już do wydarzeń wywołujących wstręt, 
związanych z naruszeniem norm „czystości”. W innych badaniach R. Giner-Sorolla i współpracownicy (Giner-Sorolla, Bosson, Caswell, Hettinger, 2012) pokazali, że zachowania seksualne mogą wywoływać gniew wtedy, gdy wiążą się z określoną krzywdą jakiejś osoby. Jednocześnie ocena zachowania seksualnego jako nietypowego wyjaśnia relację między poczuciem obrzydzenia i oceną, że jest to zachowanie niemoralne. Zatem nietypowe w percepcji danej osoby zachowania seksualne mogą być moralizowane poprzez wywoływanie odczucia wstrętu. Można się zatem spodziewać, że tendencja do moralizowania obszaru seksualności będzie wiązać się z generalnym brakiem akceptacji dla zachowań, które są nietypowe, a do takich należy cała kategoria dziecięcych zachowań seksualnych. Jonathan Haidt, Silvia Koller, i Maria Dias (1993) pokazali, że istnieją względnie stabilne różnice indywidualne w zakresie moralizowania określonych obszarów ludzkiego doświadczenia, w tym odnoszące się do traktowania obszaru seksualności jako leżącego w zakresie decyzji moralnych (tzw. kod świętość/degradacja).

\section{CEL BADANIA}

W obecnym badaniu weryfikowana jest struktura przekonań dorosłych o seksualności dzieci w wieku przedszkolnym (5-6 r.ż.) oraz predyktory tych przekonań. Pod uwagę brane są takie zmienne, jak wymiary więzi, kody moralne oraz poziom empatii. Przewiduje się, że a) wysoki poziom obaw związanych z możliwym odrzuceniem w bliskich relacjach oraz niechęć do współdzielenia planów i zamierzeń będą predyktorami negatywnych postaw względem seksualności; b) wysoki poziom empatii poznawczej będzie predyktorem pozytywnych postaw względem przynajmniej niektórych aspektów seksualności dziecięcej, z uwagi na umiejętność różnicowania motywów i uwzględniania odmienności zachowań seksualnych dzieci i osób dorosłych; c) uznawanie seksualności jako obszaru wyraźnie związanego z decyzjami moralnymi, czyli wysoka wartość sfery świętość/degradacja jako wyznacznika właściwego postępowania, będzie predyktorem negatywnej postawy względem seksualności dziecięcej, z uwagi na niski próg reakcji afektywnej w sytuacji naruszania norm tradycyjnych odnoszących się do sfery „,cielesności”.

\section{METODA}

\section{Procedura}

Uczestnicy badania. Badanie zostało przeprowadzone w drugiej połowie stycznia 2020 roku w formie zdalnej. Wyniki zbierane były przez okres dwóch tygodni. Rekrutacja uczestników badania prowadzona była metodą kuli śniegowej w serwisie społecznościowym.

$\mathrm{N}=170$ (120 kobiet i 50 mężczyzn), wiek 18-67 lat $(\mathrm{M}=30 ; \mathrm{SD}=11$; mediana $=25)$.

Jest to zatem próbka w połowie złożona z osób w okresie wczesnej dorosłości, zbliżona wiekiem do typowej populacji studentów / osób krótko po zakończeniu edukacji. W większości osoby o wyższym wykształceniu (62\%), będące obecnie w związku (74\%), ale nieposiadające na wychowaniu dzieci w wieku przedszkolnym (75\%). Jedynym kryterium doboru uczestników była pełnoletniość. Wszyscy uczestnicy wyrazili świadomą zgodę na udział poprzez zaznaczenie odpowiedniej opcji w formularzu. Zostali również poinformowani o celu badania oraz zapewnieni o jego anonimowości oraz możliwości rezygnacji $\mathrm{w}$ dowolnym momencie.

\section{NARZĘDZIA}

\section{Kwestionariusz Doświadczeń w Bliskich Związkach (Experiences in Close Relationships-Revised, ECR-R)}

Kwestionariusz autorstwa Chrisa Fraleya, Nielsa Wallera i Kelly Brennan (2000, tłum: R. Cieślak i M. Palider) służy do określenia stylu więzi i składa się z 36 pozycji, opisujących poczucie emocjonalnej bliskości i bezpieczeństwa w związkach romantycznych. Zbudowane jest z dwóch podskal: lęk (18 pozycji) oraz unikanie (18 pozycji). Pozycje na skali lęku odnoszą się do emocjonalnego uzależnienia się od partnera oraz lęku przed odrzuceniem (np. „Często pragnę, aby uczucia mojego partnera do mnie były 
tak silne, jak moje uczucie do niej/do niego"). Skala unikania zawiera pozycje odnoszące się do trudności wynikających $\mathrm{z}$ bycia w emocjonalnej bliskości z partnerem (np. ,Wolę nie być zbyt blisko moich partnerów"). Odpowiedzi na skali 7-punktowej: od 0 (zdecydowanie nie zgadzam się) do 6 (zdecydowanie zgadzam się).

\section{Kwestionariusz Kodów Moralnych (Moral Foundations Questionnaire - Polish, MFQ-PL)}

Kwestionariusz MFQ-PL (Jarmakowski-Kostrzanowski, Jarmakowska-Kostrzanowska, 2016) służy do pomiaru różnic indywidualnych w zakresie tego, w jakim stopniu poszczególne sfery ludzkiego doświadczenia są istotne przy dokonywaniu ocen i podejmowaniu decyzji moralnych. Wyróżnione kody moralne to: troska/krzywda, sprawiedliwośćloszustwo, lojalność/zdrada, autorytet/bunt i świętość/degradacja (Haidt, 2007). Kwestionariusz składa się z 30 pozycji. Połowa odnosi się do tego, na ile dane kryterium jest dla osoby badanej ważne podczas dokonywania oceny konkretnego zachowania (np. „Przy ocenie czyjegoś zachowania jako dobre lub złe jak ważny jest dla Pani/Pana fakt, czy ktoś troszczył się o kogoś słabego lub bezbronnego"). Połowa zawiera pozycje, których stopień akceptacji pośrednio wskazuje na ważność danego fundamentu moralnego (np. „Jeśli ustanawia się nowe prawo, to najważniejsze jest, aby wszyscy byli traktowani sprawiedliwie"). Odpowiedzi na skali sześciostopniowej: od 1 (zdecydowanie nieważne / zdecydowanie nie zgadzam się) do 6 (zdecydowanie ważne / zdecydowanie zgadzam się).

\section{Podstawowa Skala Empatii dla Dorosłych (Basic Empathy Scale - Adults, BES-A)}

Kwestionariusz (Carré, Stefaniak, D'Ambrosio, Bensalah, Besche-Richard, 2013, tłum.: M. Dolistowski i Ł. Tanaś) składa się z 20 pozycji. Autorzy oryginalnej wersji kwestionariusza sugerują możliwość zastosowania rozwiązania dwu- lub trójczynnikowego (Carré i in., 2013). Na podstawie konfirmacyjnej analizy czynnikowej podjęto decyzję o zastosowaniu rozwiązania dwuczynnikowego w polskiej wersji. Szczegóły analizy znajdują się w materia- łach dodatkowych dostępnych na stronie: osf. io/m569a. Czynniki odnoszą się do empatii emocjonalnej (11 pozycji), rozumianej jako wysoki/niski próg inicjowania własnych reakcji afektywnych w odpowiedzi na postrzegane emocje (np. „Staję się smutny/a, gdy widzę, jak ktoś inny płacze") oraz empatii poznawczej (9 pozycji), rozumianej jako zdolność rozumienia przyczyn i trafnego rozpoznania stanów afektywnych innych osób (np. „Zazwyczaj dostrzegam to, gdy moi przyjaciele czymś się niepokoją"). Każdemu stwierdzeniu została przyporządkowana pięciostopniowa skala ocen od 1 (zdecydowanie nie zgadzam się) do 5 (zdecydowanie zgadzam się).

\section{Kwestionariusz Przekonań Dorosłych o Ekspresji Seksualnej Dzieci Przedszkolnych (KPESDP)}

Narzędzie opracowane przez Pasikowskiego i Ratkowską-Pasikowską (2013) na podstawie zestawu zachowań seksualnych dzieci w wieku przedszkolnym. Składa się z 28 pozycji. W oryginalnej wersji kwestionariusza zastosowano siedmiostopniową skalę odpowiedzi z etykietami od 1 (zupełnie nieprawidłowe) do 7 (zupełnie normalne i typowe). W obecnym badaniu uznano, że zastosowanie takiej skali jest problematyczne, gdyż łączy ona kwestię wartościowania zachowania (,nieprawidłowe”) i ocenę jego frekwencji (,typowe”). Celem obecnego badania nie jest uzyskanie od respondentów szacunków odnośnie do frekwencji zachowań, lecz ocena postawy względem nich. Zastosowano zatem termin ,prawidłowe”, ponieważ rozumiany jest on jako: poprawne, należyte, zgodne z normami kulturowymi, podczas gdy termin ,typowe” oznacza: często spotykane, skupiające w sobie charakterystyczne cechy zjawiska. Ostatecznie uczestnicy badania oceniają dane zachowanie na skali od 1 (zupełnie nieprawidłowe) do 7 (zupełnie prawidłowe). Jednocześnie, w dalszej części pracy, stosowany jest termin ,akceptacja zachowań seksualnych" do opisu wzrostu wartości liczbowych w kontekście tych ocen. Należy mieć świadomość, że zastosowanie tego terminu jest uproszczeniem mającym na celu zwięzłość i sprawność komunikacji. Większa ,akceptacja” nie oznacza bezwarunkowej zgody danej osoby 
na wszelkie rodzaje zachowań seksualnych, niezależnie od ich kontekstu. Przykładowo, wybór średnich wartości na skali może oznaczać, że dana osoba jest skłonna uznawać dane zachowanie za poprawne czy zgodne $\mathrm{z}$ normami kulturowymi tylko w niektórych kontekstach i w tym sensie charakteryzuje się wyższą ,akceptacją" tego zachowania od osoby, która traktuje je jako zupełnie nienależyte.

\section{WYNIKI}

\section{Strategia analityczna}

Pierwszym celem obecnego badania było wykonanie eksploracyjnej analizy czynnikowej (EFA) kwestionariusza kPESDP, który za- wiera 28 pozycji. Podążając za rekomendacją dotyczącą wielkości próby $(N=\min 5 *$ liczba pozycji; Hair i in., 2013), planowano badanie $N>140$. Podjęto decyzję o zastosowaniu metody rotacji Oblimin, spodziewając się skorelowania czynników oraz analizy równoległej (parallel analysis). To metoda ekstrakcji czynników, w której liczba wyodrębnionych czynników jest ustalana na podstawie porównania ze zbiorem danych losowych wygenerowanych dla próby o tej samej wielkości i tej samej liczby zmiennych (Hayton, Allen, Scarpello, 2004). Dane analizowano przy użyciu programu JASP (2020). Dane surowe oraz raporty dostępne są na stronie: osf.io/m569a. Statystyki opisowe przedstawia tabela 1 .

Tabela 1. Statystyki opisowe

\begin{tabular}{|l|c|c|c|c|}
\hline & $M$ & SD & Min & Max \\
\hline Czynnik 1 & 3.14 & 1.22 & 1.00 & 6.92 \\
\hline Czynnik 2 & 5.07 & 1.13 & 1.92 & 7.00 \\
\hline Empatia emocjonalna & 3.59 & .77 & 1.10 & 5.00 \\
\hline Empatia poznawcza & 3.99 & .61 & 1.78 & 5.00 \\
\hline Troska/krzywda & 5.24 & .64 & 2.83 & 6.00 \\
\hline Sprawiedliwośćloszustwo & 4.79 & .62 & 3.00 & 6.00 \\
\hline Lojalność/zdrada & 3.27 & .89 & 1.00 & 5.33 \\
\hline Autorytet/bunt & 3.07 & .93 & 1.00 & 5.33 \\
\hline Świętość/degradacja & 3.42 & 1.14 & 1.00 & 6.00 \\
\hline Styl więzi: lęk & 2.04 & 1.21 & .11 & 5.06 \\
\hline Styl więzi: unikanie & 1.72 & .91 & .17 & 64 \\
\hline Wiek & 30.14 & 11.01 & \\
\hline
\end{tabular}




\section{Eksploracyjna analiza czynnikowa}

Test sferyczności Bartletta był istotny $\chi^{2}$ (378) $=3552.83, p<.001$, a test KMO osiągnął wartość .93, co pozwala uznać znaczną ade- kwatność danych względem założeń analizy czynnikowej. Analiza równoległa sugeruje wyodrębnienie dwóch czynników, które wyjaśniają łącznie 52\% wariancji (patrz: tabela 2).

Tabela 2. Ładunki czynnikowe EFA

\begin{tabular}{|c|c|c|c|}
\hline Pozycja & Czynnik 1 & Czynnik 2 & Unikalność \\
\hline 9 & .922 & & .333 \\
\hline 15 & .895 & & .346 \\
\hline 19 & .701 & & .336 \\
\hline 11 & .693 & & .333 \\
\hline 6 & .586 & & .500 \\
\hline 25 & .577 & & .553 \\
\hline 18 & .574 & & .482 \\
\hline 26 & .564 & & .458 \\
\hline 13 & .543 & & .462 \\
\hline 17 & .518 & & .602 \\
\hline 21 & .449 & & .482 \\
\hline 5 & .430 & & .500 \\
\hline 22 & .421 & .458 & .392 \\
\hline 20 & .419 & .449 & .407 \\
\hline 28 & .406 & & .559 \\
\hline 4 & & .831 & .336 \\
\hline 23 & & .828 & .429 \\
\hline 16 & & .760 & .281 \\
\hline 14 & & .723 & .472 \\
\hline 27 & & .631 & .708 \\
\hline 12 & & .577 & .441 \\
\hline 2 & & .572 & .485 \\
\hline 1 & & .534 & .596 \\
\hline
\end{tabular}




\begin{tabular}{|c|c|c|c|}
\hline Pozycja & Czynnik 1 & Czynnik 2 & Unikalność \\
\hline 3 & & .534 & .765 \\
\hline 8 & & .472 & .520 \\
\hline 7 & & .466 & .413 \\
\hline 24 & & .431 & .475 \\
\hline 10 & & & .713 \\
\hline
\end{tabular}

Uwagi. Zastosowano rotację Oblimin.

Najwyższe ładunki w Czynniku 1 uzyskały pozycje: 9 (,Stosowanie w towarzystwie rówieśników wulgarnych wyrazów, wyrażeń lub zwrotów na określenie genitaliów lub stosunków seksualnych”), 15 („Używanie w obecności dorosłych wulgarnych wyrazów, wyrażeń lub zwrotów na określenie genitaliów lub stosunków seksualnych”) oraz 19 („Dotykanie intymnych okolic ciała innych dzieci”) i 11 („Wzajemne manipulacje przy narządach płciowych w kontaktach z dziećmi”). Najwyższe ładunki w Czynniku 2 uzyskały pozycje 4 („Namawianie innych dzieci do zabaw seksualnych, np. w lekarza, w dom itp.”), 23 („Oglądanie własnych narządów płciowych”), 16 („Dotykanie i drażnienie własnych genitaliów podczas kąpieli i wycierania się”) oraz 14 („Bawienie się $\mathrm{z}$ innymi dziećmi w zabawy z podtekstem seksualnym, np. w lekarza, w małżeństwo, w dom, w narzeczeństwo"). Interpretacja treści obydwu czynników sugeruje, że Czynnik 1 odnosi się do zachowań przekraczających interpersonalne normy społeczne, związanych z agresją słowną lub potencjalnym naruszaniem intymności innych osób. Czynnik 2 odnosi się z kolei do zachowań, które można interpretować jako nawiązujące do schematów postępowania łączących seksualność z ciekawością i odgrywaniem ról (,zabawa w lekarza; dom”; zainteresowanie własnymi genitaliami). Korelacja pomiędzy czynnikami była pozytywna i dość silna, $r=.629$. Sugeruje to, że z jednej strony uczestnicy badania wyodrębniają przynajmniej dwie kategorie dziecięcych zachowań seksualnych, ale nie są to zmienne ortogonalne, widać tendencję do większej lub mniejszej akceptacji obszaru seksualności dziecięcej jako całości.

Należy również zwrócić uwagę, że szereg pozycji ma ładunki dość niskie, w przedziale .4-.5, a pozycje 20 (,Odtwarzanie w kontaktach $\mathrm{z}$ innymi dziećmi scen zaobserwowanych z seksualnego życia dorosłych, np. pocałunki, przytulania, imitowanie aktów seksualnych") oraz 22 („Pocieranie intymnymi częściami ciała o różne przedmioty”) mają ładunki powyżej wartości .4 w obu czynnikach. Sugeruje to, że wiele z wymienionych przykładów zachowań jest ambiwalentnych, to znaczy nie ma wśród respondentów zgodności co do tego, czy są to zachowania motywowane ciekawością, czy też potencjalnie niebezpieczne naruszenia norm. Przygotowując dane do dalszych analiz, obliczono odrębne wskaźniki sumaryczne dla Czynnika 1 „Naruszanie norm” oraz Czynnika 2 „Ciekawość/zabawa”, pomijając przy tym pozycje 20 oraz 22 .

\section{STYL WIĘZI, EMPATIA I KODY MORALNE JAKO PREDYKTORY POSTAW WZGLĘDEM SEKSUALNOŚCI DZIECIĘCEJ}

W celu zweryfikowania hipotez przeprowadzono dwie regresje liniowe, gdzie predyktorami były wyżej wymienione zmienne oraz wiek, płeć i fakt osobistego wychowywania dzieci w wieku przedszkolnym, a zmienną wynikową były skale „Naruszanie norm” oraz „Ciekawość/zabawa". 
Przy skali „Naruszanie norm” jako zmiennej wynikowej model regresji jest istotny, $F_{(12,157)}=7.325, p<.001$, a skorygowane $R^{2}=.3$. Istotnymi predyktorami pozytywnych postaw względem zachowań na skali „Naruszanie norm" są wymiar lęku stylu więzi, $\beta=.267, p$ $<.001$, empatia poznawcza, $\beta=.18, p<.05$ oraz fakt wychowywania dziecka w wieku przed- szkolnym, $\beta=.175, p<.05$. Natomiast istotnymi predyktorami negatywnych postaw względem zachowań na tejże skali - wymiar unikania stylu więzi, $\beta=-.205, p<.01$ oraz wysoka waga kodu świętość/degradacja, $\beta=-.304$, $p<.01$. Empatia afektywna, wiek, płeć oraz pozostałe kody moralne nie są istotnymi predyktorami (tabela 3).

Tabela 3. Współczynniki dla Czynnika 1 „Naruszanie norm”

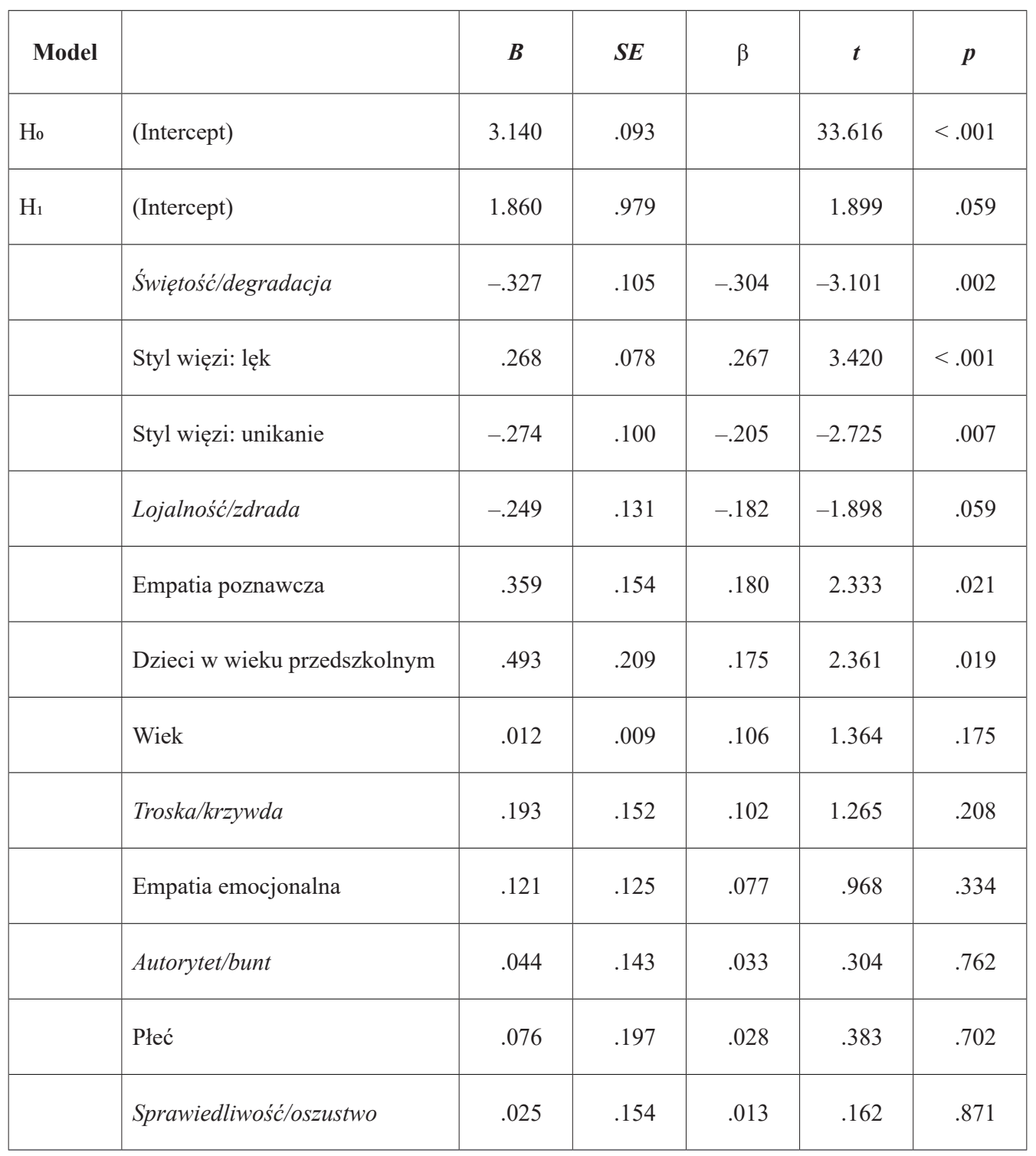


Przy skali „Ciekawość/zabawa” jako zmiennej wynikowej model regresji jest istotny, $F_{(12,157)}=9.039, p<.001$, a skorygowane $R^{2}=.363$. Istotnymi predyktorami pozytywnych postaw względem zachowań na skali „Ciekawości/zabawy" są wysoka waga kodu troska/ $k r z y w d a, \beta=.219, p<.01$, empatia poznawcza, $\beta=.173, p<.05$ oraz fakt wychowywa- nia dziecka $w$ wieku przedszkolnym, $\beta=.161$, $p<.05$. Wysoka waga kodu świętość/degradacja, $\beta=-.264, p<.01$ jest istotnym predyktorem negatywnych postaw względem zachowań na tejże skali. Wymiar lęku stylu więzi, wymiar unikania stylu więzi, empatia afektywna, wiek, płeć oraz pozostałe kody moralne nie są istotnymi predyktorami (tabela 4).

Tabela 4. Współczynniki dla C2 „Ciekawość/zabawa”

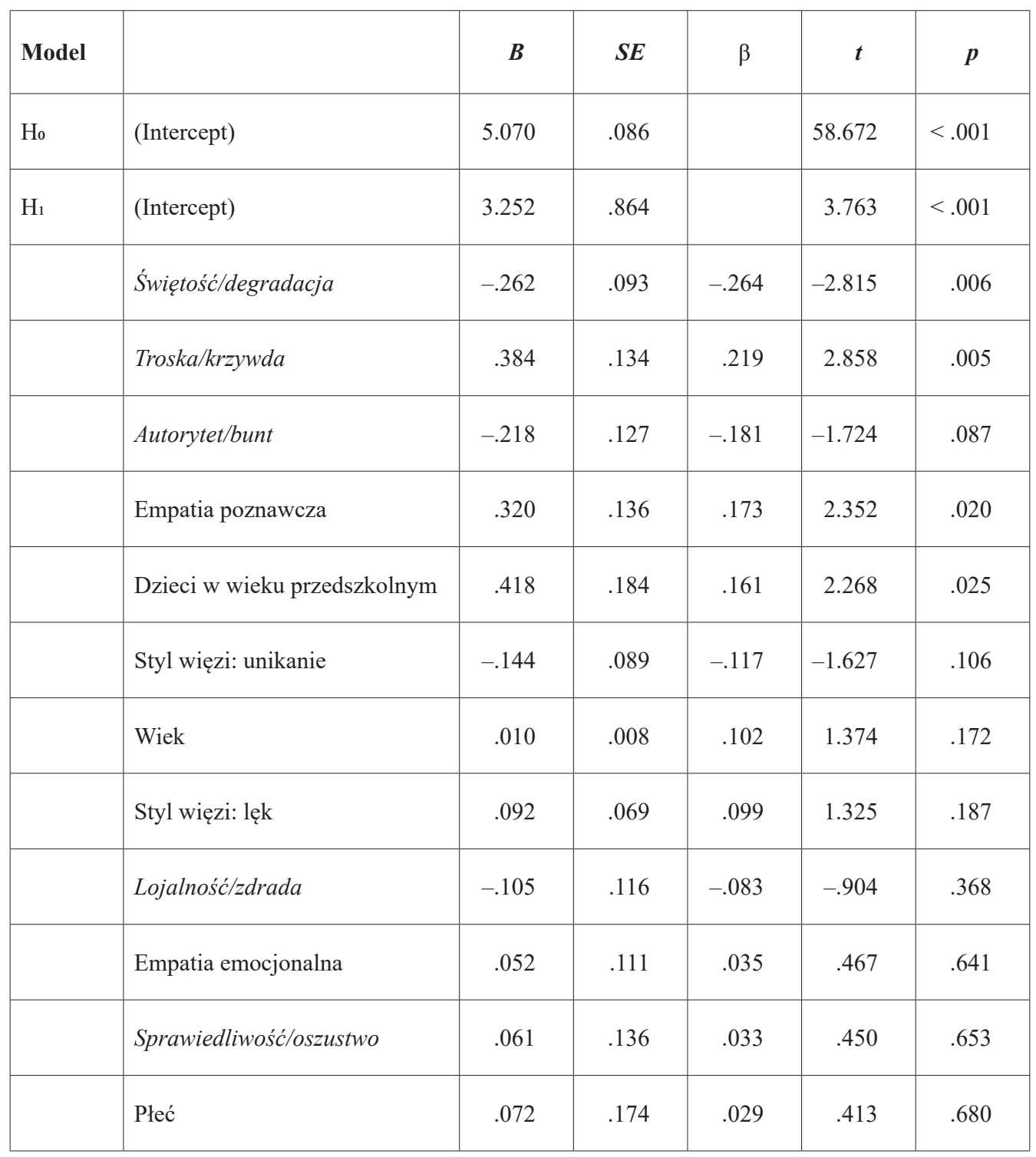




\section{Dyskusja}

Celem badania było poznanie struktury przekonań osób dorosłych o seksualności dzieci przedszkolnych oraz weryfikacja, czy wymiary więzi, kody moralne oraz poziom empatii będą predyktorami tych przekonań. Wyniki badania potwierdzają przypuszczenia odnośnie do niejednorodności struktury poglądów osób dorosłych na temat zachowań seksualnych dzieci przedszkolnych. W zestawie różnorodnych zachowań, które uwzględnione są w kwestionariuszu ekspresji seksualnej dzieci przedszkolnych (Pasikowski, Ratkowska-Pasikowska, 2013), można odnaleźć wiązkę takich, które uznawane są za raczej prawidłowe, których prototypowymi przykładami są zabawy społeczne i zachowania indywidualne łączące seksualność z ciekawością własnego ciała i odgrywaniem ról. Z drugiej strony istnieje wiązka zachowań uznawanych za raczej nieprawidłowe, do których należy stosowanie wulgarnego słownictwa czy naruszanie intymności rówieśników. Należy mieć ten fakt na uwadze, prowadząc badania, których celem byłoby szacowanie frekwencji zachowań dzieci na podstawie obserwacji prowadzonych przez rodziców. Rodzice mogą szczególnie niechętnie raportować zachowania uznawane przez nich za nieprawidłowe. Jednocześnie można się spodziewać różnic indywidualnych w zakresie takich interpretacji. Analiza tabeli ładunków czynnikowych (tabela 2) pokazuje, że wiele zachowań wymienionych w kwestionariuszu trafia do jednej lub drugiej kategorii, ale nierzadko oceny są ambiwalentne. Przykładowo, dorośli raczej uznają, że kPDESDP_28: „Oglądanie i dotykanie narządów płciowych zwierząt" to zachowanie po stronie grupy „Naruszanie norm”, ale nie jest ono odległe od kategorii „Ciekawość/zabawa”. Z drugiej strony pozycja kPDESDP_24, „Podglądanie rówieśników" raczej przynależy do wiązki „Ciekawość/zabawa”, ale jednocześnie blisko jej do „Naruszanie norm”.

Należy jednocześnie podkreślić dwie kwestie. W obecnym badaniu znacząco zmieniono kafeterię odpowiedzi na pytania kwestionariusza ekspresji seksualnej dzieci przedszkolnych (Pasikowski, Ratkowska-Pasikowska, 2013, patrz: Narzędzia), nie należy zatem dokonywać bezpośrednich porównań zależności, np. korelatów postaw, uzyskanych w obu badaniach. Ponadto przynależność poszczególnych pozycji testu do wyszczególnionych czynników mogłaby być inna, gdyby próba była reprezentatywna dla wszystkich dorosłych żyjących w Polsce. Możliwe jest też, że struktura czynnikowa narzędzia byłaby bardziej jednorodna, gdyby w próbie znalazło się mniej młodych dorosłych, a więcej osób w starszym wieku. Można się spodziewać pewnych zmian pokoleniowych w odniesieniu do ogólnej akceptacji rozmów na tematy związane z seksualnością. Populacją w obecnym badaniu były głównie kobiety z wyższym wykształceniem, mieszkające w dużych miastach, w wieku wczesnej dorosłości, będące obecnie w związku, ale niekoniecznie wychowujące dzieci w wieku przedszkolnym. Jest to populacja istotna z perspektywy celu badania, gdyż są to osoby, których poglądy obecnie odgrywają bądź w niedalekiej przyszłości będą odgrywać istotną rolę w kwestii wychowania dzieci w wieku przedszkolnym, ale niewątpliwie nie można jej utożsamić z populacją wszystkich dorosłych Polaków. W tym kontekście warto zauważyć, że jednym $\mathrm{z}$ istotnych predyktorów akceptacji zachowań seksualnych dzieci przedszkolnych okazało się faktyczne wychowywanie dzieci w tym wieku. Osoby, dla których kwestia ta nie jest już jedynie abstrakcyjną normą kulturową czy społecznie przyjętym poglądem, lecz łączy się z aktualnym doświadczeniem ich dzieci, są bardziej skłonne akceptować te zachowania. Może to stanowić optymistyczny prognostyk dla możliwości prowadzenia dalszych badań w tym obszarze, gdzie współpraca ze strony rodziców jest niezbędna. Podsumowując, wyniki obecnego badania pokazują jedynie, że możliwa jest niejednorodność struktury poglądów na temat seksualności okresu dzieciństwa, i prezentują korelaty takich poglądów, ale nie przesądzają, że taka struktura przekonań jest uniwersalna.

Kolejnym wnioskiem $\mathrm{z}$ badania jest to, że poziomy akceptacji zachowań w obu wyszczególnionych czynnikach są ze sobą pozytywnie i dość silnie skorelowane. Sugeruje to, że oprócz pewnej niejednorodności poglądów osoby z badanej populacji jednak różnią się między sobą 
generalną akceptacją lub brakiem akceptacji względem seksualności dzieci przedszkolnych, a być może względem seksualności w ogóle. Wyniki badania pokazują, że uznawanie zachowań seksualnych za raczej prawidłowe współwystępuje z wyższym poziomem empatii poznawczej, natomiast uznawanie ich za raczej nieprawidłowe z wysoką intensywnością odczuwania emocji przy postrzeganiu naruszeń norm z zakresu świętość/degradacja. Mechanizmy tych zależności wydają się odrębne, ponieważ nie ma istotnej korelacji pomiędzy poziomem empatii poznawczej i wagą kodu świętość/degradacja $(r=-.14$, n.i. $)$.

Empatia poznawcza to w dużej mierze umiejętność przyjęcia perspektywy drugiej osoby, co wymaga odseparowania własnych poglądów od wnioskowania na temat poglądów innych osób. Jest to szczególnie trudne w przypadku wnioskowania o stanach umysłowych dzieci, których schematy poznawcze są jakościowo różne od schematów osób dorosłych (Barrouillet, 2015). Również w aspekcie seksualności aktywność dziecięca, pod względem motywacyjnym, jakościowo różni się od aktywności osób dorosłych. Retrospekcje dorosłych sugerują, że pierwsze zainteresowania erotyczne innymi osobami występują ok. 10 roku życia (Bonner, Diamond, Dickenson, 2015). Pojawienie się popędu seksualnego (pożądania) zapewne związane jest ze zmianami hormonalnymi spowodowanymi zwiększonym wydzielaniem androgenów kory nadnerczy (adrenarche) (Herdt, McClintock, 2000). Z badań wynika, iż proces ten najczęściej rozpoczyna się wśród dzieci ośmio-, dziesięcioletnich, a dużo rzadziej u młodszych (Bonner $\mathrm{i}$ in., 2015). Oznacza to, że w wielu przypadkach zachowania dzieci przedszkolnych związane z nagością czy genitaliami nie będą w ogóle związane $\mathrm{z}$ motywacją seksualną, a będą przejawem ich ciekawości lub reakcją na doznania płynące z tej, niekiedy przypadkowej, aktywności. Potwierdzają to badania Larsson i Svedin (2001), w których stwierdzono, że frekwencja zachowań seksualnych dzieci przedszkolnych jest dość niewielka. Rodzice raportowali, że większość wymienionych zachowań pojawiła się jedynie „raz lub dwa razy”. Ponadto większość tych zachowań była związana z zainte- resowaniem swoimi/czyimiś erogennymi częściami ciała lub brakiem samoświadomości czy niewykształconą jeszcze umiejętnością odczuwania wstydu, np. ,chodzenie nago po domu”.

Uzyskana w badaniu relacja pomiędzy moralizacją seksualności i generalnym brakiem akceptacji zachowań seksualnych jest zgodna z przewidywaniami. Nie ma powodu, by sądzić, że osoby, które traktują zachowania seksualne raczej jako naruszające normy czystości, wywołujące wstręt czy nieprzyzwoite, będą skłonne czynić wyjątek dla zachowań seksualnych okresu dzieciństwa. Wręcz przeciwnie. Poprzez skojarzenie dzieciństwa z okresem niewinności i czystości emocje te mogą być jeszcze bardziej nasilone, a zachowania seksualne w tym okresie uznawane jako ,niezgodne z naturą". Poprzez ,naturę” można tu rozumieć pewien zestaw przekonań światopoglądowych budujących określoną wizję ,zachowań godnych człowieka". Jak wynika z przytoczonych na wstępie badań (np. Russell, Giner-Sorolla, 2013), takie oceny $z$ trudem poddają się poznawczej reinterpretacji i, z perspektywy osób odczuwającej dane emocje, są wręcz oczywiste i nie wymagają uzasadnień. Ciekawym wątkiem w kolejnych badaniach może być sprawdzenie interakcji pomiędzy empatią poznawczą a siłą reakcji afektywnych $\mathrm{w}$ odniesieniu do postrzeganych naruszeń norm z zakresu świętość/degradacja. Przykładowo, warto odpowiedzieć na pytanie, czy wzrost poziomu empatii poznawczej i zwiększenie umiejętności różnicowania motywów działania może przełożyć się na większą zdolność reinterpretacji poznawczej postrzeganych naruszeń.

Analizując wyniki dotyczące kodów moralnych, warto zauważyć, że silne reakcje na naruszenia troski/krzywdy współwystępują z większą akceptacją zachowań seksualnych w czynniku ,ciekawości/zabawy”. Można przypuszczać, że pomimo pewnego dyskomfortu, który zachowania seksualne dzieci mogą wywoływać u rodziców, osoby, dla których istotna jest kwestia troski, uznają je za prawidłowe, istotne dla ich rozwoju. Jednocześnie jednak można byłoby się spodziewać, że wystąpi ujemna korelacja pomiędzy wymiarem troski/ $k r z y w d y$ i uznawaniem za prawidłowe zacho- 
wań w czynniku „Naruszanie norm”, gdzie można doszukiwać się potencjalnej krzywdy innych osób. Relacji takiej jednak nie zanotowano. Być może dlatego, że respondenci przyjęli głównie perspektywę ,aktora” lub nie uznawali takich zachowań za świadomie, intencjonalnie krzywdzące, ale kwestia ta wymaga dalszych badań.

Relacja między akceptacją seksualności a stylem więzi nie była w pełni zgodna z oczekiwaniami. Wysoki poziom lęku okazał się pozytywnym, a wysoki poziom unikania negatywnym predyktorem uznawania zachowań z obszaru „Naruszanie norm” jako prawidłowe. Nie jest zatem tak, że bezpieczny styl więzi jest ogólnym predyktorem akceptacji dziecięcych zachowań seksualnych, np. poprzez fakt posiadania bardziej rozbudowanych skryptów komunikacyjnych dotyczących seksualności jako takiej. Postawiona hipoteza była zapewne zbyt mało specyficzna. Wydaje się raczej, że uzyskane wyniki uwidaczniają charakterystykę postaw względem zachowań seksualnych w relacji do specyfiki modelu pozabezpiecznych relacji interpersonalnych. Szymczyk i Trzęsowska-Greszta (2014) argumentują, że lękowy styl więzi sprzyja traktowaniu seksualności jako narzędzia do utrzymania w relacjach bliskości, łączy się z akceptacją zaangażowania w zachowania seksualne pomimo braku na nie ochoty i większą akceptacją zachowań ryzykownych. W obu przypadkach dochodzi zatem do większej akceptacji naruszania norm w obszarze sek- sualności. Z kolei unikający styl przywiązania przewiduje chęć poszukiwania dystansu w obszarze zarówno bliskości fizycznej z partnerem, jak i intymności. Takie oczekiwania odnośnie do bliskich relacji mogą uwrażliwiać na wszelkie sytuacje potencjalnego naruszania intymności, a głównie z takimi mamy do czynienia w zachowaniach dziecięcych opisanych w wiązce „Naruszanie norm”. W rezultacie widzimy, że powiązane ze stylem więzi postawy względem seksualności ujawniają się wyłącznie w odniesieniu do zachowań seksualnych szczególnie kłopotliwych interpersonalnie.

Podsumowując, obecne badanie wykazało, że struktura przekonań osób dorosłych względem zachowań seksualnych okresu dzieciństwa może być zróżnicowana. Jednocześnie wyniki ujawniają szereg predyktorów tych przekonań, które związane są z mechanizmami opieki, nawiązywania relacji, percepcji społecznej oraz afektywnych reakcji moralnych. Daje to możliwość prowadzenia dalszych badań nad tymi podstawowymi mechanizmami poznania społecznego. Niedostatek informacji odnośnie do zachowań seksualnych pojawiających się na wczesnych etapach rozwoju może ograniczyć możliwość pomocy tym, u których seksualność powoduje problemy medyczne i emocjonalne. Istotne jest zatem, by wspierać dalsze badania empiryczne nad tym zagadnieniem, a rodzice są w takich projektach kluczowymi partnerami dla badaczy.

\section{BIBLIOGRAFIA}

Barrouillet P. (2015), Theories of cognitive development: From Piaget to today. Developmental Review, 38, 1-12. Baxter L.A., Akkoor C. (2011), Topic Expansiveness and Family Communication Patterns. Journal of Family Communication, 11(1), 1-20.

Beisert M. (2006), Rozwojowa norma seksuologiczna jako kryterium oceny zachowań seksualnych dzieci i młodzieży. Dziecko krzywdzone, 16, 1-15.

Bird G., Viding E. (2014), The self to other model of empathy: providing a new framework for understanding empathy impairments in psychopathy, autism, and alexithymia. Neuroscience and Biobehavioral Reviews, 47, 520-532.

Bonner S.B., Diamond L.M., Dickenson J. (2015), The Development of Sexuality. Handbook of Child Psychology and Developmental Science, 1-44.

Carré A., Stefaniak N., D’Ambrosio F., Bensalah L., Besche-Richard C. (2013), The Basic Empathy Scale in adults (BES-A): factor structure of a revised form. Psychological Assessment, 25(3), 679-691. 
Styl więzi, empatia i kody moralne jako predyktory postaw względem zachowań seksualnych...

Cheng Y., Chen C., Lin C.-P., Chou K.-H., Decety J. (2010), Love hurts: An fMRI study. NeuroImage, 51(2), 923-929.

Churchland P.S. (2013), Moralność mózgu. Kraków: Copernicus Center Press.

Dąbkowski M., Dąbkowska M. (2014), Badanie zachowań seksualnych dzieci i młodzieży - problemy etyczne i metodologiczne. Psychiatria i Psychologia Kliniczna, 14(2), 106-111.

Decety J., Cowell J.M. (2014), The complex relation between morality and empathy. Trends in Cognitive Sciences, 18(7), 337-339.

Decety J., Svetlova M. (2012), Putting together phylogenetic and ontogenetic perspectives on empathy. Developmental Cognitive Neuroscience, 2(1), 1-24.

Earp B.D., Everett J.A.C., Madva E.N., Hamlin J.K. (2014), Out, Damned Spot: Can the "Macbeth Effect" Be Replicated? Basic and Applied Social Psychology, 36(1), 91-98.

Edwards, K. (1990), The interplay of affect and cognition in attitude formation and change. Journal of Personality and Social Psychology, 59(2), 202-216.

Fraley R.C., Waller N.G., Brennan K.A. (2000), An item response theory analysis of self-report measures of adult attachment. Journal of Personality and Social Psychology, 78(2), 350-365.

Giner-Sorolla R., Bosson J.K., Caswell T.A., Hettinger V.E. (2012), Emotions in sexual morality: testing the separate elicitors of anger and disgust. Cognition Emotion, 26(7), 1208-1222.

Gino F., Kouchaki M., Galinsky A.D. (2015), The Moral Virtue of Authenticity: How Inauthenticity Produces Feelings of Immorality and Impurity. Psychological Science, 26(7), 983-96.

Goldsmith K.M., Dunkley C.R., Dang S.S., Gorzalka B.B. (2016), Sexuality and romantic relationships: investigating the relation between attachment style and sexual satisfaction. Sexual and Relationship Therapy, 31(2), 190-206.

de Graaf H., Rademakers J. (2011), The psychological measurement of childhood sexual development in Western societies: methodological challenges. Journal of Sex Research, 48(2-3), 118-129.

de Graaf H., Vanwesenbeeck I., Woertman L., Meeus W. (2011), Parenting and adolescents' sexual development in western societies. European Psychologist, 16(1), 21-31.

Haidt, J. (2007), The new synthesis in moral psychology. Science, 316(5827), 998-1002.

Haidt J., Koller S.H., Dias M.G. (1993), Affect, culture, and morality, or is it wrong to eat your dog? Journal of Personality and Social Psychology, 65(4), 613-628.

Hair J.F., Black W.C., Babin B.J., Anderson R.E. (2013), Multivariate Data Analysis. Pearson Education Limited.

Hayton J.C., Allen D.G., Scarpello V. (2004), Factor Retention Decisions in Exploratory Factor Analysis: a Tutorial on Parallel Analysis. Organizational Research Methods, 7(2), 191-205.

Henrich J., Heine S.J., Norenzayan A. (2010), Most people are not WEIRD. Nature, 466(7302), 29.

Herdt G., McClintock M. (2000), The magical age of 10. Archives of Sexual Behavior, 29(6), 587-606.

Hrdy S.B. (2011), Mothers and Others: The Evolutionary Origins of Mutual Understanding. The Belknap Press.

Jarmakowski-Kostrzanowski T., Jarmakowska-Kostrzanowska L. (2016), Polska adaptacja Kwestionariusza kodów moralnych (MFQ-PL). Psychologia Społeczna, XI(39), 489-508.

Jolliffe D., Farrington D.P. (2006), Development and validation of the Basic Empathy Scale. Journal of Adolescence, 29(4), 589-611.

Josephs M., Rakoczy H. (2016), Young children think you can opt out of social-conventional but not moral practices. Cognitive Development, 39, 197-204.

Keelan J.P.R., Dion K.K., Dion K.L. (1998), Attachment style and relationship satisfaction: Test of a selfdisclosure explanation. Canadian Journal of Behavioural Science. Revue Canadienne Des Sciences Du Comportement, 30(1), 24-35.

Lamb M.E., Lerner R.M. (2015), Handbook of child psychology and developmental science: Socioemotional processes, Vol. 3. John Wiley Sons Inc.

Lamm C., Batson C.D., Decety J. (2007), The neural substrate of human empathy: effects of perspective-taking and cognitive appraisal. Journal of Cognitive Neuroscience, 19(1), 42-58.

Lamm C., Bukowski H., Silani G. (2016), From shared to distinct self-other representations in empathy: evidence from neurotypical function and socio-cognitive disorders. Philosophical Transactions of the Royal Society of London. Series B, Biological Sciences, 371(1686), 20150083. 
Larsson I., Svedin C.-G. (2001), Sexual behaviour in Swedish preschool children, as observed by their parents. Acta Paediatrica, 90, 436-444.

MacNeil S., Byers E.S. (2009), Role of sexual self-disclosure in the sexual satisfaction of long-term heterosexual couples. Journal of Sex Research, 46(1), 3-14.

Nichols S. (2002), Norms with feeling: Towards a psychological account of moral judgment. Cognition, 84(2), 221-236.

O'Sullivan L.F., Meyer-Bahlburg H.F.L., Watkins B.X. (2001), Mother-daughter communication about sex among urban African American and Latino families. Journal of Adolescent Research, 16(3), 269-292.

Pasikowski S., Ratkowska-Pasikowska J. (2013), Przekonania dorosłych na temat seksualności dzieci w wieku przedszkolnym. Dyskusja i badania w kontekście zagadnienia czynników zagrożenia marginalizacją. Problemy Wczesnej Edukacji, IX(2 (21), 73-89.

Passanisi A., Gervasi A.M., Madonia C., Guzzo G., Greco D. (2015), Attachment, self-esteem and shame in emerging adulthood. Procedia-Social and Behavioral Sciences, 191(1), 342-346.

Rehman U.S., Lizdek I., Fallis E.E., Sutherland S., Goodnight J.A. (2017), How Is Sexual Communication Different from Nonsexual Communication? A Moment-by-Moment Analysis of Discussions Between Romantic Partners. Archives of Sexual Behavior, 46(8), 2339-2352.

Russell P.S., Giner-Sorolla R. (2013), Bodily moral disgust: what it is, how it is different from anger, and why it is an unreasoned emotion. Psychological Bulletin, 139(2), 328.

Sabo J.S., Giner-Sorolla R. (2017), Imagining wrong: Fictitious contexts mitigate condemnation of harm more than impurity. Journal of Experimental Psychology. General, 146(1), 134-153.

Simpson J.A., Overall N.C. (2014), Partner Buffering of Attachment Insecurity. Current Directions in Psychological Science, 23(1), 54-59.

Szymczyk B., Trzęsowska-Greszta E. (2014), Styl przywiązania a seksualność człowieka w świetle najnowszych badań. Kwartalnik Naukowy Fides et Ratio, 4(20), 128-143.

Theiss J.A., Estlein, R. (2014), Antecedents and Consequences of the Perceived Threat of Sexual Communication: A Test of the Relational Turbulence Model. Western Journal of Communication, 78(4), 404-425.

de Waal F.B.M. (2008), Putting the altruism back into altruism: the evolution of empathy. Annual Review of Psychology, 59, 279-300.

West C., Zhong C.-B. (2015), Moral cleansing. Current Opinion in Psychology, 6, 221-225.

Zhong C.-B., Liljenquist K. (2006), Washing away your sins: threatened morality and physical cleansing. Science, 313(5792), 1451-1452. 